\title{
The influence of "One Belt And One Road" national strategy on the transnational operation of China's retail industry -- empirical analysis based on questionnaire
}

\author{
Liyan Pan \\ School of business, Shanghai jianqiao University, Shanghai 201306, China; \\ liyanpan@gench.edu.cn
}

\begin{abstract}
Keywords: One Belt And One Road, Retail industry, Questionnaire investigation, Statistical analysis

Abstract. This paper obtained first-hand data from Chinese domestic retail entrepreneurs and experts in the field of retail industry on the development of China's retail industry in One Belt And One Road countries, especially those with economic and trade relations with China, as well as Retail related industries cluster into "One Belt And One Road" countries, and by applying some methods such as theoretical analysis and mathematics statistics to summarized valuable results.
\end{abstract}

\section{Introduction}

The proposal of One Belt And One Road national strategy has provided huge space choice and market opportunity for Chinese enterprises to go out, including retail industry. Key decision-making areas such as overseas target market selection and market entry of China's retail industry are highly consistent with One Belt And One Road in concept and highly overlapping in content. On the one hand, China's retail industry must make full use of the strategic opportunities brought by One Belt And One Road and accelerate the pace of "going global". On the other hand, by "going global" in the retail industry, we will expand the trade field, optimize the trade structure, and promote trade balance, so as to enrich and diversify the connotation of the construction of "One Belt And One Road" economic belt. Therefore, China's retail industry should give priority to countries and regions along the "One Belt And One Road" that have signed investment protection agreements, free trade zones and overseas economic and trade cooperation zones with China (Zhu ruiting, 2016). First, we can give full play to the advantages of regional concentration strategy and reduce transnational operation risks. Second, these markets have fewer restrictions on China's export trade, which is more beneficial for Chinese enterprises to acquire the advanced technology and scarce resources, and then provide an effective channel for China's retail industry and its related industries to go out in groups. Many countries along One Belt And One Road are closely related to China in geography and culture, which is the main driving factor for retail enterprises to select overseas target markets. However, it is not enough to consider only these two factors. The market proximity model for the selection of target markets for transnational operation of retail enterprises is expanded from the market proximity triangle model composed of three basic elements of geography, economy and culture to the market proximity pentagon model consisting of culture, economy, society, public policy and retail structure (Wang xuhui, 2005).

\section{Research Method}

A. Questionnaire design

The empirical research method adopted in this study is the questionnaire survey method to explore the relationship between the development of five links / the advantages of related industries docking willingness and feasibility. At present, there is no mature scale for the research on the internationalization of Chinese retail enterprises under the background of One Belt And One Road. According to (Dunn et al., 1994; Hinkin, 1995), we took the following steps to develop a scale suitable for One Belt And One Road retail enterprises to select target markets.

1. Search the literature, preliminary design measurement items;

2. Conduct in-depth exchange and discussion with academic experts and retail enterprise managers 
to improve the measurement items;

3. Conduct a preliminary survey, and further evaluate and modify the initial questionnaire to form the final questionnaire.

In the questionnaire, for the convenience of the interviewees filling in and statistical processing, we designed each question according to Likert's five-point scoring method, which means :1= complete opposition; $2.2=$ against; $3=$ neutral; $4=$ agree; $5=$ full agreement.

B. The main content of the questionnaire, sample selection and questionnaire recovery

The questionnaire is divided into enterprise questionnaire and expert questionnaire. In this paper, the final questionnaire was used for formal investigation, and the members of the research group sent questionnaires to the interviewees by email, and keeping them complete all work on time actively.

1. The enterprise questionnaire

The questionnaire is divided into three parts. The first part is the general evaluation and judgment of the interviewed enterprises on Chinese retail enterprises "going global", including the judgment on the overseas influence of Chinese retail enterprises "going global" and the necessity and feasibility of "going global" under the background of One Belt And One Road; The second part is to evaluate the influence of One Belt And One Road on the "going global" of Chinese retail industry, including the relationship between One Belt And One Road national strategy and Chinese retail enterprises' "going global", the function of "five links", as well as the impact of China's retail industry's relative industrial advantages on China's retail enterprises' "going global", these problems are included in the theoretical model of this study; The third part is the basic information of the enterprises and the basic situation of "going global".

The selection of enterprise samples is dominated by the top 100 Chinese chain stores in 2015 released by China chain management association in May 2016. In the specific sample selection of enterprises, foreign retail enterprises operating in China mainland were strictly excluded. To ensure the representativeness of survey samples, on this basis, the geographical distribution, business type, enterprise scale, enterprise nature, and business model should be considered as much as possible. The questions in this questionnaire are related to the strategic decision-making of enterprises. Therefore, those who have completed the questionnaire are all senior managers who are familiar with the strategic participation of enterprises. In order to ensure the integrity and reliability of enterprise information obtained, questionnaire survey of some enterprises was completed by several senior managers of an enterprise respectively.

The survey distributed questionnaires to 43 enterprises, 41 enterprises were eventually obtained, 58 questionnaires were collected. The sample situation is shown in table 1:

Table 1 Enterprise sample situation

\begin{tabular}{c|c|c}
\hline Property & Category & Sample size \\
\hline \multirow{4}{*}{$\begin{array}{c}\text { Distribution } \\
\text { area }\end{array}$} & Eastern & 21 \\
\cline { 2 - 3 } & North & 10 \\
\cline { 2 - 3 } & Central & 5 \\
\cline { 2 - 3 } & South & 3 \\
\cline { 2 - 3 } & Southwest & 1 \\
\hline \multirow{4}{*}{$\begin{array}{c}\text { Ranked } \\
\text { among the top }\end{array}$} & Northeast & 1 \\
\cline { 2 - 3 } stores in 2015 & Top 10 & 6 \\
\cline { 2 - 3 } & $11-20$ & 7 \\
\cline { 2 - 3 } & Outside the top 100 & 7 \\
\hline
\end{tabular}

2. The expert questionnaire 
The content design of the expert questionnaire is consistent with the first part and the second part of the enterprise questionnaire, so as to compare the results of the enterprise questionnaire and the expert questionnaire, and analyze the differences and similarities between the enterprise and the experts on the same question. The interviewed experts were mainly BBS experts with 30 people in circulation industry in China, all of whom were well-known experts in the domestic circulation industry and international business research, and finally obtained 45 expert questionnaires. In this paper, the data obtained from enterprise questionnaire and expert questionnaire are tested by means of mean value.

Test result display there is no significant difference in the judgment of enterprises and experts on China's retail industry going global under the background of One Belt And One Road. Therefore, the enterprise questionnaire and expert questionnaire were combined and 103 valid questionnaires were included in this paper.

\section{Main results}

In order to determine whether variables are distinguishable among interviewees, the study first use SPSS for reliability analyses, for later evaluate the reliability of variables in subsequent studies, reliability analysis is needed. With the purpose of achieve the goal of simplifying the system structure and grasping the essence of the problem, multiple indicators are transformed into several comprehensive indicators (main components) on the premise of little information loss. The idea of linear transformation be applied to explain the variance-covariance structure of multiple variables by using the comprehensive index, and the principal component analysis and factor analysis of the data should be further carried out .For the sake of investigate the correlation between One Belt And One Road national strategy and other factors that promote Chinese enterprises to go out, correlation regression analysis was carried out. Aim to investigate the correlation between the variable One Belt And One Road's national strategy has pushed Chinese retailers out and other factors, correlation regression analysis was performed.

\section{Summary and enlightenment}

The investigation result of One Belt And One Road national strategy's influence on the transnational operation of China's retail industry has been tested by the five-level scale, which is highly reliable and the variables used are reasonable and need not be debugged. Experts are divided on the competitive advantage of China's manufacturing and logistics industries in countries along the One Belt And One Road line (but the data show that the reliability is still within the acceptable range). If these two variables are removed in subsequent studies, the overall credibility of the investigation will be increased.

According to the analysis, among the influencing factors of overseas investment in Chinese retail industry, the most favorable factor is One Belt And One Road national strategy and its five links. China's retail industry should actively align with the national strategy of One Belt And One Road and take countries along One Belt And One Road as the preferred target market for transnational operation. China's retail industry should adopt the mode of correlative industrial clusters to go global, and give priority to developing the markets of countries along One Belt And One Road that have close economic and trade relations with China, this is the lowest risk and cost for the transnational operation of China's retail industry. Logistics and finance are China's industries with obvious advantages along One Belt And One Road. The financial industry can provide funds for the transnational operation of retail industry, the significance is apparent. Logistics distribution is the basis of efficient operation of retail industry, nowadays, especially in many countries; young consumers are more likely to go online shopping. As a result, consumers are no longer visiting big stores, choosing smaller ones that are more local, this change has rebuild the logistics system and led to the multi-channel shopping model and multi-channel supply chain (Ying jing, 2016). However, the growth rate of online shopping in China is significantly faster than that of developed countries, and it has obvious advantages in logistics distribution, which will help Chinese retail industry, especially export e-commerce B2C, and enter the market of countries along One Belt And One Road.

Among the selection factors of target market on Chinese retail in One Belt And One Road, cultural affinity is not decisive. In other words, Chinese retailing can invest in countries 
with great national cultural differences. The advantages of China's manufacturing industry and transportation industry cannot help One Belt And One Road national strategy to connect with the transnational operation of China's retail industry. On the one hand, the infrastructure of countries along One Belt And One Road is generally backward, and the advantages of China's transportation industry cannot radiate to One Belt And One Road until a large amount of investment and construction of the transportation system is completed. On the one hand, the infrastructure of countries along One Belt And One Road is generally backward, and the advantages of China's transportation industry cannot radiate to One Belt And One Road until a large amount of investment and construction of the transportation system is completed. One Belt And One Road's national strategy runs through seven cultural regions in Europe, Russia, west Asia and north Africa, subsaharan Africa, South Asia, east Asia and southeast Asia. There are various cultural differences in languages, religious beliefs, economic development stages, production modes, social forms, lifestyles, customs and habits, and that leads to a huge difference in consumer demand. In the early stages of entering the country market along One Belt And One Road, China's retail industry should give up the advantages of Chinese manufacturing and adopt more localization strategy, including product, price, channel, promotion and other aspects of localization. Among them, the localization of products should actively adapt to the differences in local consumers' tastes and demands, adapt to the differences in social culture and different lifestyles, and adapt to the local competitive behaviors, considering the significance and influence of products on consumers' psychology and take care of local consumers' purchasing methods. Under the influence of these factors, Chinese retail enterprises are likely to purchase local products in One Belt And One Road target market countries at the initial stage of market entry. The advantage is that local people can accept Chinese retailers as local enterprises.

\section{References}

[1] Zhu ruiting, the linkage development of China's retail industry's going out strategy under the background of One Belt And One Road [J], economic system reform,2016(3),18-23.

[2] Wang xuhui. Overseas market selection mechanism of international retailers - interpretation based on market proximity model and psychological distance [J]. China's industrial economy, 2005(7):119126.

[3] Dunn S C, Seaker R F, Waller M A. Latent variables in business logistics research: Scale development and validation [J]. Journal of Business logistics, 1994(2): 145-172.

[4] Hinkin T R. A review of scale development practices in the study of organizations [J]. Journal of Management, 1995, 21(5): 967-988.

[5] Ying jing, One Belt And One Road will drive the growth of logistics in 58 countries - talk to general manager of UK Cirrus logistics, Chinese business, 2016(2), 104-107. 